\title{
Pengaruh Kepuasan Kerja terhadap Kinerja Karyawan
}

\author{
Alfian Nurrohmat*, Rini Lestari \\ Prodi Akuntansi, Fakultas Ekonomi dan Bisnis, Universitas Islam \\ Bandung, Indonesia. \\ *ariestafin@gmail.com,rini_lestari@unisba.ac.id
}

\begin{abstract}
Job satisfaction can improve the performance of employees of a company. The phenomenon that occurs at PT Kahatex in Bandung Regency shows that poor job satisfaction can result in employees often going in and out and not surviving in the company for a long period of time. In addition, the implementation of activities with main tasks and functions that are not in accordance with the expectations of the organization is the result of poor employee performance. This investigation means to have the option to clarify work fulfillment, representative execution and the greatness of the impact of occupation fulfillment on worker execution at PT Kahatex in Bandung Regency. The sample in this study was PT Kahatex in Bandung Regency, namely all employees at PT Kahatex in Bandung Regency. The information assortment method utilized is as a survey with 30 respondents. The example determination method in this examination is a non-probability sampling technique with a convenience sampling technique. Hypothesis testing used is simple linear regression. The results showed that job satisfaction and employee performance at PT Kahatex in Bandung Regency were included in the "good" criteria. Job satisfaction has an effect on employee performance at PT Kahatex in Bandung Regency.
\end{abstract}

Keywords: Job Satisfaction, Employee Performance

Abstrak. Kepuasan kerja bisa meningkatkan performa karyawan suatu perusahaan. Fenomena yang terjadi pada PT Kahatex Kabupaten Bandung menunjukan bahwa kepuasan kerja yang buruk dapat mengakibatkan karyawan sering keluar masuk dan tidak bertahan dalam jangka waktu cukup panjang di perusahaannya. Selain itu, pelaksanaan kegiatan-kegiatan dengan tugas pokok dan fungsi yang belum sesuai dengan harapan organisasi merupakan akibat dari kinerja karyawan yang buruk. Penyelidikan ini berarti memiliki pilihan untuk memperjelas pemenuhan pekerjaan, pelaksanaan perwakilan dan besarnya dampak pemenuhan pekerjaan terhadap pelaksanaan pekerja di PT Kahatex di Kabupaten Bandung. Sampel dalam penelitian ini adalah PT Kahatex di Kabupaten Bandung yaitu seluruh karyawan pada PT Kahatex di Kabupaten Bandung. Metode pengumpulan informasi yang digunakan adalah survei dengan 30 responden. Contoh metode penentuan dalam pemeriksaan ini adalah non probality sampling dengan teknik convenience sampling. Pengujian hipotesis yang digunakan adalah regresi linier sederhana. Hasil penelitian menunjukan bahwa kepuasan kerja dan performa karyawan pada PT Kahatex di Kabupaten Bandung termasuk dalam kriteria "Baik". Kepuasan kerja berpengaruh terhadap Kinerja karyawan pada PT Kahatex di Kabupaten Bandung.

Kata Kunci: Kepuasan Kerja, Kinerja karyawan 


\section{A. Pendahuluan}

\section{Latar Belakang}

Karyawan amat penting bagi perusahaan diawali dengan merekrut karyawan yang terbaik dibidangnya lalu kemudian menyediakan sarana dan sumber tenaga yang dibutuhkan termasuk pelatihan-pelatihan jauh jangkauannya dan masuk akal, dengan tujuan agar para perwakilan dapat terus meningkatkan keterampilan mereka dan menjadikan tenaga kerja terbaik di bidangnya masing-masing. Perwakilan dengan pemenuhan jabatan yang tinggi tentunya memiliki inspirasi kerja yang tinggi, sehingga pelaksanaan pekerjaannya juga akan ideal. Kemudian lagi, perwakilan dengan pemenuhan pekerjaan yang rendah menyebabkan pelaksanaan pekerjaan yang tidak berdaya. Mereka menjadi tidak rajin dalam bekerja, dan ini sangat menghambat organisasi.

Salah satu fenomena yang diidentikkan dengan eksekusi pekerja dipisahkan oleh pandemi Covid-19, yang memiliki konsekuensi intens untuk setiap bidang keuangan, terutama bidang peningkatan pekerjaan, khususnya bahan dan pakaian di tanah air. Gabungan dua 'pemain' material yang signifikan, PT Sri Rejeki Isman Tbk (SRIL) atau Sritex dan PT Pan Brothers Tbk (PBRX) berada di bawah faktor tekanan yang sangat besar.

Terkait Sritex, organisasi yang didirikan oleh almarhum HM Lukminto itu kini menghadapi faktor tekanan keuangan yang luar biasa. Sejak tahun ini hingga tahun berikutnya organisasi memiliki kewajiban yang akan berkembang dalam jumlah yang cukup besar. Demikian pula Sritex tercatat mengalami penurunan jumlah perwakilan sepanjang tahun 2020 . Seperti yang ditunjukkan oleh laporan tahunan review 2020 yang beredar di situs Bursa Efek Indonesia (BEI), jumlah pekerja Sritex per 31 Desember 2020 mencapai 17.186 perwakilan. Angka ini turun 8,4\% atau berkurang 1.577 berbanding tahun 2019 yang sebanyak 18.763 perwakilan. Untuk sementara, struktur jumlah pekerja pada tahun 2020 terdiri dari 17.082 perwakilan dari bagian penciptaan dan 104 pekerja dari bagian non-ciptaan. Para petinggi Sritex juga mengklarifikasi alasan penurunan jumlah pekerja organisasi. Pelaksana SRIL menyatakan, Penurunan jumlah pekerja Sritex disebabkan karena usia yang tidak produktif dan sesuai dengan strategi organisasi untuk menyelesaikan produktivitas pelaksanaan dengan teknik peningkatan kemampuan untuk perwakilan, sehingga terjadi penurunan pada pekerja yang memiliki kemampuan di bawah standar yang telah ditetapkan (Rabu, Juni 2021).

Sepanjang tahun lalu, tulis manajemen SRIL, perseroan menghadapi sebagian tantangan/kendala dalam usaha menempuh sasaran yang suda ditentukan. Hal demikian mencakup penangguhan jaringan toko, penurunan minat lokal dan global, penayangan terputus yang sampai sekarang tidak dapat diakses tepat sasaran serta berkaitan dengan kesehatan semua karyawan dari virus Covid-19.

\section{Tujuan}

Menurut latar belakang diatas peneliti tertarik untuk meneliti sejauh mana keadaan performa pada PT Kahatex di Kabupaten Bandung dengan meninjau aspek kepuasan kerja dan performa Perwakilan. Mengingat penggambaran di atas, pencipta tertarik untuk mengarahkan penelitian dengan judul: "Pengaruh Kepuasan Kerja Terhadap Kinerja Karyawan (Studi empiris pada PT Kahatex di Kabupaten Bandung)". Selanjutnya, Berdasarkan uraian pada latar belakang diatas maka persoalan yang dapat diidentifikasi sebagai berikut:

1. Bagaimana kepuasan kerja pada PT Kahatex di Kabupaten Bandunh?

2. Bagaimana kinerja karyawan pada PT Kahatex di Kabupaten Bandung?

3. Seberapa besar kepuasan kerja berpengaruh terhadap kinerja karyawan pada PT Kahatex di Kabupaten Bandung?

\section{B. Metodologi Penelitian}

Metode penelitian pada dasarnya merupakan cara ilmiah untuk mendapatkan data dengan tujuan dan kegunaan tertentu dengan ciri-ciri keilmuan yaitu rasional, empiris, dan sistematis (Sugiyono, 2014:2). Adapun metode penelitian yang digunakan dalam penelitian ini yaitu metode deskriptif dengan pendekatan kuantitatif. Menurut Sugiyono (2012:29) metode deskriptif adalah metode yang berfungsi untuk mendeskripsikan atau memberi gambaran 
terhadap objek yang diteliti melalui data atau sampel yang telah terkumpul sebagai mana adanya, tanpa melakukan analisis dan membuat kesimpulan yang berlaku umum. Sedangkan Menurut Sugiono (2013:13) metode penelitian kuantitatif dapat diartikan sebagai metode penelitian yang berlandaskan pada filsafat positivme, digunakan untuk meneliti pada populasi atau sampel tertentu, teknik pengambilan sampel pada umumnya dilakukan random, pengumpulan data menggunakan instrumen penelitian, analisis data bersifat kuantitatif/statistik dengan tujuan untuk menguji hipotesis yang telah ditetapkan.

\section{Hasil Penelitian dan Pembahasan}

Gambaran unit analisis akan membahas mengenai populasi dan sampel penelitian, gambaran umum mengenai subjek yang dijadikan sampel dalam penelitian ini serta deskripsi umum karakteristik responden. Peneliti memperoleh data penelitian dengan menyebar kuesioner sebanyak 30 lembar, setiap satu dari survei dikembalikan dan memiliki jawaban total.

Jumlah responden dalam penelitian ini sebanyak 30 responden yang merupakan karyawan PT Kahatex Kabupaten Bandung. Karakteristik responden dapat diklasifikasikan berdasarkan jenis kelamin, usia, pendidikan terakhir, dan jabatan.

Diketahui bahwa dari 30 responden sebanyak 17 orang $(56,7 \%)$ berjenis kelamin perempuan dan 13 orang $(43,3 \%)$ berjenis kelamin laki-laki. Hal ini menunjukan para karyawan yang bekerja di PT Kahatex Kabupaten Bandung lebih banyak berjenis kelamin perempuan.

Diketahui bahwa dari 30 responden sebanyak 13 orang $(43,3 \%)$ berusia antara $26-30$ tahun dan 8 orang $(26,7 \%)$ berusia diatas 30 tahun. Hal ini menunjukan karyawan yang bekerja di PT Kahatex Kabupaten Bandung rata-rata berusia antara 26-30 tahun.

Diketahui bahwa dari 30 responden sebanyak 29 orang $(96,7 \%)$ memiliki latar belakang pendidikan dari SMA dan 1 orang $(3,3 \%)$ memiliki latar belakang pendidikan dari S1. Hal ini menunjukan karyawan yang bekerja di PT Kahatex Kabupaten Bandung memiliki latar belakang dari SMA.

Diketahui bahwa dari 30 responden sebanyak 21 orang $(70 \%)$ memiliki jabatan sebagai karyawan dan 1 orang $(3,3 \%)$ memiliki jabatan sebagai mandor, operator, pewarna kain dan QC. Hal ini menunjukan paling banyak karyawan yang bekerja di PT. Kahatex Kabupaten Bandung bekerja sebagai staf.

Dalam penelitian ini, analisis regresi linier sederhana digunakan untuk membuktikan sejauh mana pengaruh kepuasan kerja terhadap kinerja karyawan.

Tabel 1. Uji Regresi Linear Sederhana

\begin{tabular}{|c|c|c|c|c|c|}
\hline \multicolumn{6}{|c|}{ Coefficients $^{a}$} \\
\hline \multirow[t]{2}{*}{ Model } & \multicolumn{2}{|c|}{ Unstandardized Coefficients } & \multirow{2}{*}{\begin{tabular}{|c|} 
Standardized Coefficients \\
Beta
\end{tabular}} & \multirow[t]{2}{*}{$\mathrm{T}$} & \multirow[t]{2}{*}{ Sig. } \\
\hline & $\mathrm{B}$ & Std. Error & & & \\
\hline (Constant) & 9.771 & 3.480 & & 2.808 & .009 \\
\hline Kepuasan Kerja & .565 & .119 & .668 & 4.751 & .000 \\
\hline
\end{tabular}

a. Dependent Variable: Kinerja Karyawan

Bentuk persamaan dalam penelitian ini adalah sebagai berikut:

$\mathrm{Y}=\mathbf{9 , 7 7 1}+\mathbf{0 , 5 6 5}(\mathrm{X})$

Jika diinterpretasikan sebagai berikut :

1. Nilai konstanta variabel kinerja karyawan adalah 9,771 artinya tanpa adanya pengaruh kepuasan kerja, maka nilai kinerja karyawan sudah ada sebesar 9,771 satuan.

2. Nilai koefisien regresi kinerja karyawan adalah 0,565 menunjukan arah yang positif artinya setiap peningkatan 1 satuan kepuasan kerja, maka kinerja karyawan akan meningkat sebesar 0,565 satuan.

Analisis koefisien determinasi dilakukan untuk mengetahui besaran (persentase) pengaruh kepuasan kerja terhadap kinerja karyawan dengan hasil sebagai berikut: 
Berdasarkan uraian diatas besarnya angka $\mathrm{R}$ square (R2) adalah 0,446 atau 44,6\%. Artinya kepuasan kerja berpengaruh sebesar $44,6 \%$ terhadap kinerja karyawan sedangkan sisanya sebesar 55,4\% dipengaruhi oleh variabel lain yang tidak diteliti dalam penelitian ini.

\section{Kesimpulan}

Berdasarkan hasil penelitian dan pembahasan pengaruh kepuasan kerja terhadap kinerja karyawan di PT Kahatex Kabupaten Bandung, maka dapat ditarik beberapa kesimpulan sebagai berikut:

1. Secara keseluruhan kepuasan kerja pada karyawan PT Kahatex Kabupaten Bandung dikategorikan cukup puas.

2. Secara keseluruhan kinerja karyawan PT Kahatex Kabupaten Bandung dikategorikan baik.

3. Kepuasan kerja berpengaruh signifikan terhadap kinerja karyawan di PT Kahatex Kabupaten Bandung.

\section{Acknowledge}

Penulis mengucapkan terima kasih kepada seluruh pihak yang telah membantu dan mendukung dalam memberikan data maupun informasi untuk menyelesaikan penelitian ini.

\section{Daftar Pustaka}

[1] Sofianty, Diamonalisa, Nuhayati, Rachman, Rosdiana. 2018. Statistik Penelitian Dengan SPSS. Bandung: Laboratorium Akuntansi FEB UNISBA.

[2] Sugiyono. 2005. Memahami Penelitian Kualitatif Bandung: CV. Alfabeta.

[3] 2010. Metode Penelitian Kuantitatif Kualitatif dan R\&D. CV. Bandung: Alfabeta.

[4] _.2012 Metode Penelitian Kuantitatif Kualitatif dan R\&D. Bandung: Alfabeta.

[5] 2014. Metode Penelitian Pendidikan Pendekatan Kuantitatif, Kualitatif, dan $R \& D$. Bandung: Alfabeta.

[6] Juniantara, Riana, 2015. Pengaruh motivasi dan kepuasan kerja terhadap kinerja karyawan koperasi di denpasar E-Jurnal Ekonomi dan Bisnis Universitas Udayana: Bali. ISSN: 23373067.

[7] Handoko, T. Hani. 2001. Manajemen Personalia dan Sumber Daya Manusia. Yogyakarta: BPFE Yogyakarta.

[8] Ibrahim, Meimoon. 2017. "Effect of Internal Control Coorporate Governance, Organizational Culture and Management Audit on Managerial Performance Evidence from Indonesia" International Journal of Economic Perspectives ISSN: 1307-1637 2017, Volume 11, Issue 3, 1826-1832.

[9] Arda, 2017. Pengaruh Kepuasan Kerja Dan Disiplin Kerja Terhadap Kinerja Karyawan Pada Bank Rakyat Indonesia Cabang Putri Hijau Medan. Jurnal Ilmiah Manajemen \& Bisnis Vol. 18 No. 1, 2017, 45-60.

[10] Wahyuddin M dan Parwanto. (2002). Pengaruh Faktor-faktor Kepuasan Kerja terhadap Kinerja Karyawan Pusat Pendidikan Komputer Akuntansi IMKA di Surakarta. Tesis. Surakarta: Universitas.Muhammadiyah Surakarta.

[11] Kuncoro, M. (2009). Metode Riset Untuk Bisnis dan Ekonomi. Yogyakarta: Erlangga.

[12] Mangkunegara, A. P. (2001). Manajemen Sumber Daya Manusia Perusahaan. Bandung: Remaja Rosda Karya 